\title{
ThE POLITY DEBATE REGARDING GAY AND LESBIAN ORDINATION AND/ or installation in the Presbyterian Church (U.S.A.)
}

Author:

Roché F. Vermaak ${ }^{1}$

\section{Affiliation:}

${ }^{1}$ Presbyterian Church

(U.S.A.), Brentwood

Presbyterian Church, Los

Angeles, USA

\section{Correspondence to:}

Roché Vermaak

email:

vermaak@verizon.net

Postal address:

2512, 28th Street, Apt 101,

Santa Monica, CA, 90405, USA

\section{Keywords:}

'definitive guidance'; gay/ lesbian ordination; General Assembly Permanent Judicial Commission; The Book of Confessions; the Book of Order

\section{Dates:}

Received: 09 July 2009

Accepted: 10 May 2010

Published: 23 Sept. 2010

How to cite this article: Vermaak, R.F., 2010, 'The polity debate regarding gay and lesbian ordination and/or installation in the Presbyterian Church (U.S.A.)', Verbum et Ecclesia 31(1), Art. \#51, 10 pages. DOI: 10.4102/ve.v31i1.51

This article is available at: http://www.ve.org.za

C 2010 . The Authors. Licensee: OpenJournals Publishing. This work is licensed under the Creative Commons Attribution License.

\section{ABSTRACT}

The paper summarises the formation process of the Presbyterian Church (U.S.A.)'s (PC(USA)) polity regarding the ordination and/or installation of partnered gays and lesbians as officers, i.e. deacons, elders and ministers of the Word and Sacrament, in light of General Assemblies' decisions and General Assembly Permanent Judicial Commissions' ecclesiastical rulings since the 1970s.

\section{INTRODUCTION}

This paper expands on my first paper (Vermaak 2010) and traces the development of polity decisions regarding gay and lesbian ordination and/or installation by General Assemblies from 1978 onwards and judicial rulings issued by the Presbyterian Church (U.S.A.)'s (PC(USA)) highest ecclesiastical court, the General Assembly Permanent Judicial Commission (GAPJC). Despite the PC(USA) and its predecessor churches - the United Presbyterian Church in the U.S.A. (UPCUSA) and the Presbyterian Church in the U.S. (PCUS) - discussing and studying same-gender relationships for more than forty years, it is no closer to a solution. This is mostly due to the three denominations dealing with the debate through polity means, not through theology and discussion, the lasting result of the recommendation of the Special Commission of 1925 (PCUSA Minutes 1927:58-86).

The polity of the PC(USA) is formed by its Constitution, consisting of The Book of Confessions (Part I) and the Book of Order (italicised since 1983, Part II) and Authoritative Interpretations of the Constitution which can be issued by the General Assembly (majority of the 752 commissioners) or the GAPJC (majority of the 18 members). The Constitution can be amended through the General Assembly approving an overture from a presbytery or commissioners' resolution, on recommendation by the Assembly Committee on the Constitution (ACC), which it sends as an amendment to the presbyteries to ratify. A majority vote, i.e. 87 of the 173 presbyteries, is required to change the Book of Order (G18.0301 Book of Order) and a two-thirds vote is needed to change The Book of Confessions (G-18.0201 Book of Order).

\section{THE ORDINATION AND/OR INSTALLATION OF GAY AND LESBIAN OFFICERS}

The UPCUSA and the PCUS both dealt with same-gender relationships since the 1960s. The issue of ordination (and installation) came to the fore in 1976. One needs to take note of the Presbyterian election system. Ordination is when an officer-elect is ordained and installed to the office of deacon, elder or minister of the Word and Sacrament through the laying on of hands. Installation is when an officer-elect, who was previously ordained to that specific office, is installed as an officer, without laying on of hands. All offices are perpetual (G-14.0210 Book of Order); officers are ordained for the whole church, but as history has shown, not all officers are eligible to serve in the whole church.

\section{The United Presbyterian Church in the U.S.A. and the Presbyterian Church in the U.S.}

The 1970 General Assembly of the UPCUSA approved receipt of the majority report, Sexuality and the Human Community (UPCUSA 1970:3). However, the majority report did not label homosexual acts as sin - the General Assembly did: 'We ... reaffirm our adherence to the moral law of God as revealed in the Old and New Testaments, that adultery, prostitution, fornication and/or the practice of homosexuality is $\sin ^{\prime}$ (UPCUSA Minutes 1970:469, 889). The statement that 'the practice of homosexuality is sin' would be reaffirmed by the 1976 General Assembly of the UPCUSA (UPCUSA Minutes 1976:111-112). Note should be taken that in this statement there was no theological or biblical rationale as to why the practice of homosexuality was sin. It also did not speak about the ordination of gays and lesbians as officers. It merely spoke about homosexual practice in general.

The question regarding gay and lesbian ordination was raised at the 1976 General Assembly of the UPCUSA when the Presbyteries of New York and Palisades asked for 'definitive guidance' regarding the ordination of a candidate, Mr B. Silver (Anderson 1994:3). The General Assembly created a special Task Force to study 'Christian approaches to homosexuality, with special reference to the ordination of avowed practicing homosexuals' (UPCUSA 1978b:5). The General Assembly also reaffirmed its 1970 position:

... [w] 'reaffirm our adherence to the moral law of God ... that ... the practice of homosexuality is sin.... Also we affirm that any self-righteous attitude of others who would condemn persons who have so sinned is also sin.' ('Minutes', 1970, Part I, p. 469.) The 188th General Assembly (1976) declares again its commitment to this statement. Therefore, on broad Scriptural and confessional grounds, it appears that it would at the present time be injudicious, if not improper, for a presbytery to ordain to the professional ministry of the gospel a person who is an avowed practicing homosexual.

(UPCUSA Minutes 1976:112) 
The 1977 General Assembly of the PCUS received, but did not adopt, a report, The Church and Homosexuality: A Preliminary Study. However, the General Assembly rejected homosexuality: 'Although we confess our need for more light ... [w] now believe that homosexuality falls short of God's plan for sexual relationships ...' (PCUS Minutes 1977:174). But, the General Assembly supported the civil rights of homosexuals:

... [ $\mathrm{t}$ ]he need for the Church to stand for just treatment of homosexual persons in our society in regard to their civil liberties, equal rights, and protection under the law from social and economic discrimination which is due all citizens

(PCUS Minutes 1977:174)

The 1978 and 1979 General Assemblies of the PCUS reaffirmed this decision (PCUS Minutes 1978:190; 1979:208). The PCUS, and later the PC(USA), continued to accept in practice what it rejected in theory: gays and lesbians were rejected for ordination in the church, but their civil rights should be protected.

The 1978 General Assembly of the UPCUSA received, but did not adopt, the report, The Church and Homosexuality, written by Rev B. Shafer, which included a majority report and minority report (Shafer 1978:9-56). It approved the document, The Church and Homosexuality: Policy Statements and Recommendations, in which the General Assembly spelled out its policy, gave 'definitive guidance' and offered 14 recommendations (UPCUSA Minutes 1978:261-267). It found the phrase 'homosexual persons' did not occur in the Book of Order (italicised since 1983); neither did it explicitly prohibit the ordination of self-affirming, practicing homosexual persons as officers: 'In short, the Book of Order does not give any explicit direction to presbyteries, elders, and congregations as to whether or not self-affirming, practicing homosexual persons are eligible or ineligible for ordination to office' (UPCUSA Minutes 1978:265).

Therefore, the 1978 General Assembly of the UPCUSA gave presbyteries (and sessions) the following 'definitive guidance':

That unrepentant homosexual practice does not accord with the requirements for ordination set forth in Form of Government ... 'It is indispensable that, besides possessing the necessary gifts and abilities, natural and acquired, everyone undertaking a particular ministry should have a sense of inner persuasion, be sound in the faith, live according to godliness, have the approval of God's people and the concurring judgment of a lawful judicatory of the Church.' In relation to candidates for the ordained ministry, the committees should be informed by the above guidance.

(UPCUSA Minutes 1978:265)

The 'definitive guidance' was clear: any homosexual practice was sin and excluded one from ordination. The statement implied, as was previously stated in the document, that gays and lesbians, who either married a partner of a different gender or stayed celibate, could be ordained (and/or installed) as officers, as long as they did not act on their homosexual orientation. Homosexual orientation was not wrong; acting on it was, and this excluded one from ordination (and/or installation) as an officer. Note that the 'definitive guidance' was not just directed toward the original questions regarding the ordination of a gay candidate as a minister, but extended to all church officers, i.e. deacons, elders and ministers. Recommendation 14 dealt with previously ordained officers: '[The General Assembly] [d]eclares that these actions shall not be used to affect negatively the ordination rights of any United Presbyterian deacon, elder, or minister who has been ordained prior to this date' (UPCUSA Minutes 1978:266).

It was clear that the 'definite guidance' was just that - guidance - and not a constitutional interpretation which would interfere with the power of the presbytery to ordain and install ministers (Anderson 1993:2). Despite this clear intent, the Stated Clerk of the General Assembly, Mr W.P. Thompson, had to carry out the directive. The question was whether the definitive guidance' was a statement presbyteries should take seriously when ordaining homosexuals, or if it was an Authoritative Interpretation of the Book of Order, binding upon the entire UPCUSA (North Como Presbyterian Church 2005:149-150). Thompson interpreted it the latter manner (UPCUSA 1978b:6). Whether Thompson had acted correctly in his interpretation and within his authority as Stated Clerk would become a debatable issue in the PC(USA) for decades.

The 1979 General Assembly of the PCUS adopted a paper, Homosexuality and the Church: A Position. Rather than write a new paper, the PCUS decided to use a slightly modified version of the UPCUSA's 1978 policy statement, The Church and Homosexuality (PC(USA) 2004a:63). Thus, the 1978 and 1979 'definitive guidance' statements were identical. One clarification regarding sin was added:

... [t] his paper is working with a doctrine of sin which understands it as a feature of human existence which is a much more pervasive and damaging reality than the moral deficiency of a particular act. While the practice of homosexuality is called a sin, the paper does not speak of the homosexual condition as a sin.

(PC(USA) 2004a:65)

The definition of sin was expanded to incorporate more than sex acts; it was part of the human condition. In summary, both the document by Shafer, The Church and Homosexuality, prepared for the UPCUSA in 1978, and the document, The Church and Homosexuality: A Preliminary Study, prepared for the PCUS in 1977, were not adopted, but only approved for study. Both reports had a majority view, which was more positive regarding gay and lesbian ordination, based on good theological and biblical grounds, but the UPCUSA accepted the minority view, and the PCUS did not receive the report, but made statements which reflected the minority view. The 1978 and 1979 'definitive guidance' statements - the polity of the church regarding gay and lesbian ordination - condemned 'the practice of homosexuality' on weak theological and biblical foundations, but they represented the majority view of the Presbyterian Church.

The 1982 General Assembly of the UPCUSA approved a resolution:

Therefore, the 194th General Assembly (1982) reaffirms that the guidance of the 190th General Assembly (1978) shall be carefully and prayerfully considered by all judicatories and that within the explicit requirements of the Book of Order the responsibility for deciding on the ordination of any particular member of the church rests with the responsible judicatory on the basis of the definitive guidance given to the church as a whole by the 190th General Assembly (1978) and other Assemblies.

(UPCUSA Minutes 1982:111)

The statement reaffirmed the power of local judicatories, but they were bound by the Constitution and could not ignore the 'definitive guidance' when dealing with the ordination (and/or installation) of gays and lesbians.

\section{The Presbyterian Church (U.S.A.)}

In 1983, the UPCUSA and PCUS reunited, after their split in 1861 during the Civil War, to form the PC(USA) and adopted the Articles of Agreement. Article 1.9 stated that every policy statement adopted or issued by the General Assemblies of the UPCUSA and PCUS 'shall have the same force and effect' in the PC(USA) 'until rescinded, altered or supplanted' by the General Assembly of the PC(USA) (Appendix B-3 Book of Order). Thus, the 'definitive guidance' statements by the UPCUSA in 1978 and the PCUS in 1979 had the same full effect in the PC(USA) since 1983.

Additionally, a new Book of Order was adopted at reunion. G-6.0108 was added in the Form of Government section regarding freedom of conscience: 
a. It is necessary to the integrity and health of the church that the persons who serve in it as officers shall adhere to the essentials of the Reformed faith and polity as expressed in 'The Book of Confessions' and the Form of Government. So far as may be possible without serious departure from these standards, without infringing on the rights and views of others, and without obstructing the constitutional governance of the church, freedom of conscience with respect to the interpretation of Scripture is to be maintained.

$b$. It is to be recognized, however, that in becoming a candidate or officer of the Presbyterian Church (U.S.A.) one chooses to exercise freedom of conscience within certain bounds. His or her conscience is captive to the Word of God as interpreted in the standards of the church so long as he or she continues to seek or hold office in that body. The decision as to whether a person has departed from essentials of Reformed faith and polity is made initially by the individual concerned but ultimately becomes the responsibility of the governing body in which he or she serves.

(G-1.0301; G-1.0302)

It reflects the tension found in the Adopting Act of 1729, which required subscription to the Westminster Standards, but also limited subscription to those standards that were essential and necessary (The Adopting Act of 1729). G-6.0108b would become a central issue at the 2006 General Assembly.

Besides General Assembly decisions, several ecclesiastical charges ruled upon by the GAPJC have shaped the denomination's polity on ordination. The 1985 GAPJC ruling, in Blasdell, et al. v. Presbytery of Western New York, was in regard to the possible ordination of partnered gay and lesbian Christians as officers by the Session of Westminster. However, the GAPJC erred twice in mentioning that the 1978 actions of the UPCUSA were an 'authoritative interpretation.' It incorrectly quoted the 1978 Minutes from the UPCUSA and rendered an interpretation of what it believed the 1978 and 1979 'definitive guidance' was: '... [i]n fact and in substance, authoritative interpretations of the Constitutions as they were then and as the Constitution presently exists' (PC(USA) Minutes 1985:121).

The GAPJC's view that the 'definitive guidance' was an Authoritative Interpretation was an incorrect reading and became part of the 1985 General Assembly Minutes of the PC(USA). The dissenting minority of the GAPJC correctly called the 1978 and 1979 rulings 'definitive guidance' (PC(USA) Minutes 1985:122). This erroneous pronouncement of the 1985 GAPJC regarding the 'definitive guidance', which unconstitutionally became church law through the actions of Thompson in 1978, continued to steer the PC(USA) down a slippery slope. Based on the GAPJC's view that the 'definitive guidance' was church law and had become Authoritative Interpretation, it declared: 'Therefore, it is unconstitutional for the Church to ordain any self-affirming, practicing, and unrepentant homosexual as elder, deacon, or minister of the Word' (PC(USA) Minutes 1985:121).

The issue at stake was the authority and power of the higher governing body to determine controversies. The GAPJC viewed the action of the UPCUSA in 1978, on ordaining selfaffirming, unrepentant homosexuals, to be a determination of a controversy, which was controlling over lower governing bodies until it was rescinded, altered, or supplemented. It found the Session of Westminster had committed an irregularity against the interpretation of the Constitution. The GAPJC drew this conclusion:

'We, therefore reject the notion that the General Assembly, as a higher governing body, is without authority to provide definitive guidance in the area of the requirements for ordination as elders and deacons'

(PC(USA) Minutes 1985:121).

The 1986 General Assembly affirmed again that the 'definitive guidance' of 1978 had become binding upon the whole church, until changed by a subsequent General Assembly (PC(USA)
Minutes 1986:34). The 1989 General Assembly reaffirmed the positions of the 1985 and 1986 General Assemblies (PC(USA) Minutes 1989:89).

The presbyteries approved an amendment from the 1987 General Assembly to add G-13.0103r to the Book of Order. It provides that the General Assembly, or through its GAPJC, has the right to make an Authoritative Interpretation, no longer just 'definitive guidance,' which would be constitutionally binding upon the whole church and its governing bodies. The vital part of the article was that the 'most recent interpretation ... shall be binding.' Thus, at its meetings, the General Assembly can issue an Authoritative Interpretation, which can be affirmed or replaced by a GAPJC decision and vice versa. However, one should note that since 1972, GAPJC decisions are not reviewable by the General Assembly. The 1987 General Assembly also affirmed that the 'definitive guidance' statements of 1978 and 1979 were now an Authoritative Interpretation of the Book of Order (PC(USA) Minutes 1987:66, 145-146).

The 1992 GAPJC, in LeTourneau, et al. v. Presbytery of Twin Cities Area, rescinded the certification of a candidate, Ms L. Larges, as 'ready to receive a call' because she was a lesbian, despite the fact that it could not be shown, nor was she asked, if she was an 'avowed practicing homosexual' (PC(USA) Minutes 1993:165). At most, Larges admitted to having a lesbian orientation. The 1978 and 1979 'definitive guidance' - unrepentant homosexual practice does not accord with the requirements for ordination was applied to Larges in its fullest extent.

The 1992 GAPJC, in Sallade, et al. v. Presbytery of Genesee Valley, ruled that Rev J.A. Spahr, a partnered lesbian who was ordained prior to 1978, but who later came out as a lesbian, could not be installed to a new call. The GAPJC understood that Recommendation 14 of 1978 meant:

Ordination itself, for those ordained prior to 1978, does not make them immune from the application of the broad principles of the policy statement after the date of its adoption. Recommendation fourteen of that policy statement provides protection from the removal of ordination for homosexual practices that occurred prior to its adoption. Recommendation fourteen provides amnesty for past acts but not license for present or future acts. ('Minutes', UPCUSA, 1978, Part I, p. 266)

(PC(USA) Minutes 1993:168)

The 1993 ACC, in the wake of the LeTourneau and Sallade rulings, dealt with the authority of the 1978 and 1979 'definitive guidance' statements:

[t]he General Assembly statements of 1978, 1979, and subsequent years concerning the ordination of self-affirming, practicing homosexual persons and related recommendations adopted by the General Assembly have been considered by the judicial commissions of the church. They currently carry the weight of 'authoritative interpretations'.

(PC(USA) Minutes 1993:322)

Thus, decisions by the GAPJC, which considered these earlier statements, were binding, and:

The question whether or not - in 1978, 1979, and subsequent years - it was constitutionally sound to declare the statements binding has become moot. Because of subsequent decisions of our church's highest judicial commission, the current prohibition to ordination has been determined.

(PC(USA) Minutes 1993:322)

In summary, the 1993 General Assembly recognised the 1978 and 1979 'definitive guidance' statements as an Authoritative Interpretation of the Constitution of the PC(USA):

[c]urrent constitutional law in the Presbyterian Church (U.S.A.) is that self-affirming, practicing homosexual persons may not be ordained as ministers of the Word and Sacrament, elders, or deacons.

(PC(USA) Minutes 1993:322) 
However, many questions were left unanswered. Could a gay or lesbian candidate (for ministry) or officer-elect, who did not 'self-affirm' or disclose their sexual orientation and/or relationship when interviewed by the presbytery or session, be ordained and/or installed? The 1994 General Assembly reaffirmed the 1993 General Assembly decision (PC(USA) Minutes 1994:80).

The 1993 GAPJC, in Hope Presbyterian Church v. Central Presbyterian Church, ruled that although the ordinations of two self-affirming, practicing homosexual members to the office of deacon were irregular, they would not be annulled and the officers would not be removed from office, in accordance with G-14.0203 (currently G-14.0210 Book of Order), i.e. offices are perpetual (PC(USA) Minutes 1994:142-143).

The 1995 GAPJC, in Session of Central Presbyterian Church of Huntington, NY v. Presbytery of Long Island, for the second time, did not annul but upheld the ordination of two self-affirming, practicing homosexual persons - namely, a gay and a lesbian, as deacons (PC(USA) Minutes 1996:174).

Since the 1980s, conservative presbyteries have sent overtures to the General Assembly to write the 1978 and 1979 'definitive guidance' and affirmations thereof in Authoritative Interpretations into the Book of Order, by either amending G-6.0106 and/or adding a ' $b$ ' section. They finally succeeded, when the 1996 General Assembly sent an amendment to G-6.0106 - adding a ' $b$ ' portion - to the presbyteries for their vote:

$b$. Those who are called to office in the church are to lead a life in obedience to Scripture and in conformity to the historic confessional standards of the church. Among these standards is the requirement to live either in fidelity within the covenant of marriage between a man and a woman (W-4.9001), or chastity in singleness. Persons refusing to repent of any self-acknowledged practice which the confessions call sin shall not be ordained and/ or installed as deacons, elders, or ministers of the Word and Sacrament.

(PC(USA) Minutes 1996:79-80)

The presbyteries voted 97-74 to approve Amendment $\mathrm{B}$, and G-6.0106b became part of the Book of Order in June 1997 (PC(USA) Minutes 1997:133) and, thus, constitutional law. Now there was a clear prohibition in the Book of Order and Constitution that sexual activity was only allowed in marriage and those who did not abide by it were not allowed to be ordained and/or installed. However, great uncertainty still exists regarding which sin is mentioned; what does 'chastity in singleness', 'selfacknowledged practice', and 'refusing to repent' mean; and what happens when improper ordinations and/or installations occur? (see Vermaak 2009:236-249). The General Assembly clarified that homosexual orientation was not sin, nor a barrier to ordination; same-gender sexual activity was.

A 1997 General Assembly overture to reword G-6.0106b was defeated by a $114-59$ vote by the presbyteries (PC(USA) Minutes 1998:131). The 1998 General Assembly decided not to send another amendment to delete G-6.0106b to the presbyteries, but issued an Authoritative Interpretation on G-6.0106:

That the 210th General Assembly (1998) approve the following authoritative interpretation of G-6.0106 and G-4.0403: 'Standing in the tradition of breaking down the barriers erected to exclude people based on their condition, such as age, race, class, gender, and sexual orientation, the Presbyterian Church (U.S.A.) commits itself not to exclude anyone categorically in considering those called to ordained service in the church, but to consider the lives and behaviors of candidates as individuals'.

(PC(USA) Minutes 1998:68)

The Authoritative Interpretation affirmed the church's policy that sexual orientation, specifically a gay or lesbian orientation, was not a barrier to ordained service. However, sexual practice of one's gay or lesbian orientation would still prohibit one from ordination and/or installation.

The 1998 GAPJC, in Wier v. Session of Second Presbyterian Church of Fort Lauderdale, FL (Wier I), ruled that Wier should have asked for a stay of enforcement before the ordination or installation of a partnered gay Christian took place; he should not have filed a complaint after the fact. The ordination of $\mathrm{Mr} \mathrm{R}$. Whetstone as an elder, although irregular, stood in light of G-14.0203 (currently G-14.0210 Book of Order) and the 1993 Hope ruling, i.e. his office is perpetual (PC(USA) Minutes 1999:832). The GAPJC also admonished Wier: he should have filed a disciplinary complaint, not a remedial complaint; therefore, Whetstone could not be removed from office (PC(USA) Minutes 1999:833).

The 1999 General Assembly approved the following resolution:

The 211th General Assembly (1999) affirms that the existing policy of inclusiveness welcomes all into membership of the Presbyterian Church (U.S.A.) as we confess our sin and our need for repentance and God's grace. In order to be consistent with this policy, no church should insist that gay and lesbian people need therapy to change to a heterosexual orientation, nor should it inhibit or discourage those individuals who are unhappy with or confused about their sexual orientation from seeking therapy they believe would be helpful. The Presbyterian Church (U.S.A.) affirms that medical treatment, psychological therapy, and pastoral counseling should be in conformity with recognized professional standards.

(PC(USA) Minutes 1999:80)

This resolution reaffirmed that gay and lesbian Christians were to be welcomed into membership and should not be forced to have conversion therapy to change their sexual orientation to a heterosexual orientation

The 2000 GAPJC, in Sheldon, et al. v. Presbytery of West Jersey, ruled that a gay, but celibate, inquirer, Mr G. Van Keuren, could advance to candidate (for ministry). The GAPJC found that since the presbytery had not yet conducted a final assessment of Van Keuren's readiness to begin ministry, G-6.0106b was not applicable. The 1992 GAPJC ruling in the LeTourneau decision applied wherein a candidate remained under care of the presbytery until such time as the CPM was satisfied that the candidate could be properly certified as ready to receive a call (PC(USA) Minutes 2000:590). This was the first test case that G-6.0106b did not apply to candidates, but only to those candidates being considered for ordination. The Sheldon ruling also reaffirmed that sexual orientation was not a bar to advancing to candidacy or ordination; sexual practice was.

The 2000 GAPJC, in Session of Londonderry Presbyterian Church, et al. v. Presbytery of Northern New England, acknowledged that no clear and palpable evidence existed that any improper ordination and/or installation had taken place in Christ Church Presbyterian, Burlington, Vermont after it adopted and issued a Resolution of Dissent over G-6.0106b. The opinion of the session gave a basis for concern that violations may have occurred, therefore, at a minimum, the presbytery had to inquire (PC(USA) Minutes 2001:579). The ruling allowed Christ Church to disagree with G-6.0106b, but:

This Commission finds that there are no constitutional grounds for a governing body to fail to comply with an express provision of the 'Constitution', however inartfully stated.... Furthermore, no court in our denomination has the authority to amend the Constitution or to invalidate any part of it.

(PC(USA) Minutes 2001:580-581)

Freedom of conscience was not limitless, but was bound by the Constitution. The result of the Londonderry ruling was that dozens of sessions and several presbyteries decided not to take action against sessions and individuals who defied church law regarding G-6.0106b (Adams 2002:3). 
The 2001 General Assembly sent an overture to the presbyteries that G-6.0106b be stricken, but it was defeated by a 126 to 46 vote (PC(USA) Minutes 2002:321).

The 2002 GAPJC, in Wier v. Session of Second Presbyterian Church of Fort Lauderdale, FL (Wier II), provided some clarity as to what was permissible to be asked of candidates (officers-elect) for ordination and/or installation. The GAPJC found where, as in this case regarding an elder-elect, Mr K. Barber, the specification of self-acknowledgment was absent in a complaint, it:

... [m]ay have extreme consequences to a person's reputation, career, or friendships, a greater degree of specificity is required. A complaint making such an allegation must assert factual allegations of how, when, where, and under what circumstances the individual was self-acknowledging a practice which the confessions call a sin.

(PC(USA) Minutes 2002:340-341)

Even if the allegations against Barber being a 'practicing homosexual' were true, the complaint failed to meet the specificity that G-6.0106b compelled - namely, it did not allege any such specific details. The plain language of the Constitution clearly stated disqualified persons must self-acknowledge the proscribed sin. The GAPJC added a vital distinction:

Self-acknowledgment may come in many forms. In whatever form it may take, self-acknowledgment must be plain, palpable, and obvious, and details of this must be alleged in the complaint

PC(USA) Minutes 2002:341).

The GAPJC stated, in essence, mere rumours or gossip about a candidate's sexual activity was not sufficient grounds for a complaint. It warned ' $[t]$ o single out a category of persons above and beyond other persons as more likely to sin violates the doctrine of total depravity' (PC(USA) Minutes 2002:341). The standard shifted from the 1992 GAPJC ruling in the LeTourneau case, which put sexual orientation and practice on equal footing, to the 2002 Wier II case which required self-acknowledgment regarding sexual practice in accordance with G-6.0106b. The Wier II ruling gave some integrity back to the way G-6.0106b should be applied by sessions. Questions regarding sexual activity should be based on self-acknowledgement by the candidate regarding their sexual practice, not their sexual orientation. However, the GAPJC stated:

If that governing body has reasonable cause for inquiry based on its knowledge of the life and character of the candidate, it has the positive obligation to make due inquiry and uphold all the standards for ordination and installation. Consideration for inquiry is to be made solely on an individual basis (GA 'Minutes' $68,166,1998)$. Therefore, if notwithstanding the requirement of individualized inquiry based on reasonable cause, a governing body makes a line of inquiry to a candidate without reasonable cause, all candidates currently before that governing body must undergo the same inquiry.

(PC(USA) Minutes 2002:341)

The GAPJC argued that sessions and presbyteries, besides inquiring from a candidate (officer-elect) when it had reasonable cause, could inquire from all candidates when it did not have reasonable cause and in the absence of self-acknowledgment, an exception which the 1998 Authoritative Interpretation by the General Assembly simply did not specify. Unfortunately, it has led to the practice of some sessions and presbyteries asking all candidates questions regarding their sexual activity.

The 2003 GAPJC, in McKittrick v. Session of the West End Presbyterian Church of Albany, NY, ruled that a gay elder, $\mathrm{Mr}$ $\mathrm{S}$. Edwards, should be re-examined with all due speed by the PJC of the Synod of the Northeast (SPJC) and the PJC of the Presbytery of Presbytery of Albany (PPJC), since his term would expire two months after the ruling. The GAPJC referenced the 1998 Wier I decision that an order to admonish a session to refrain from future irregular ordinations was an appropriate action (PC(USA) Minutes 2003:273). However, the time merely ran out before Edwards could be re-examined. The GAPJC again clarified that McKittrick should have filed a disciplinary complaint, not a remedial complaint, in the case of a wrongful installation. It also criticised the practice of fast ordinations and installations:

We further note that when, as in this case, an installation occurs immediately following the examination process, there may be no practical opportunity for a protesting or dissenting party to seek a stay of enforcement of the decision to install... Therefore, we encourage governing bodies to permit sufficient time between the examination and installation or ordination of a candidate so that there can be no intimation that any governing body intended to shield its action from scrutiny.

(PC(USA) Minutes 2003:274)

The 2003 GAPJC, in Presbytery of San Joaquin v. Presbytery of the Redwoods, and Hart, et al. v. Presbytery of the Redwoods, ruled that the complainants used criteria from the 1992 LeTourneau decision, prior to the inclusion of G-6.0106b in 1997, which specifies that one should repent of any self-acknowledged practice. They should have amended their complaints regarding the ordination of a lesbian candidate, Ms K. Morrison, to use the 2002 Wier II standard, which had replaced the LeTourneau standard (see above). Thus, San Joaquin argued that Morrison's self-acknowledged homosexual orientation was sufficient and left out any allegation of self-acknowledged practice. The GAPJC stated that they cured the theological defect of the Le Tourneau [sic] decision through the application of the doctrine of total depravity in Wier II. The defect was the assumption that one category of persons was more prone to sin than other categories of persons (PC(USA) Minutes 2003:280).

The GAPJC concluded:

Thus, sexual orientation alone would be no more sufficient or reasonable grounds for further questioning than would singleness, obesity or any other categorization. In other words, stereotypical profiling is not a reasonable or valid ground for singling out a candidate for additional questioning. Therefore, if a person does not self-acknowledge a practice that the confessions call sin, then a governing body has a positive obligation to make further inquiry only if it has direct and specific knowledge that said person is in violation of the ordination and installation standards of the Constitution. In order to faithfully hold the central tenet of total depravity, there must be a higher pleading specificity as to what constitutes the grounds for reasonable cause prior to inquiry. A hunch, gossip or stereotype is not a sufficient ground to compel a governing body to make further inquiry. Reasonable grounds must include factual allegations of how, when, where, and under what circumstances the individual was self-acknowledging a practice which the confessions call a sin.

(PC(USA) Minutes 2003:280)

Thus, the 2003 GAPJC again affirmed the 2002 Wier II ruling and put the focus on the essence of G-6.0106b. Self-acknowledgement of sexual practice had become the standard; without it, one could not inquire. A governing body could only inquire if it had direct and specific knowledge that the candidate was in violation of the ordination and installation standards. Factual allegations of practices, instead of hunches or gossip, would be the only acceptable measure.

The 2003 General Assembly was asked to clarify the meaning of 'chastity,' 'repent,' and 'self-acknowledgement' in G-6.0106b (PC(USA) Minutes 2003:324-325). The ACC argued that no Authoritative Interpretation was required, since the current constitutional documents and related judgments were not silent on the issue (PC(USA) Minutes 2003:325). The General Assembly followed the advice of the ACC and concluded:

A search of the electronic version of 'The Book of Confessions' easily reveals a vast number of relevant reflections on these terms from our tradition. Specific application of these standards to explicit conduct is best accomplished through the particular factfinding available through the judicial process.

(PC(USA) Minutes 2003:64) 
The 2003 General Assembly failed to clarify what the 1996 General Assembly meant when it approved G-6.0106b, and used 'chastity' in the place of 'celibacy' or 'refrain from sexual intercourse outside of marriage.' In the absence of a theological definition and discourse, based on the Confessions and Scripture, of what 'chastity' means, the PC(USA) continues to resort to polity-based decisions and statements. 'Chastity' in the Confessions is equated with modern-day 'celibacy.' Thus, the meaning of chastity is misused in G-6.0106b, since overtures with 'celibacy' repeatedly failed. This inability of General Assemblies to honestly struggle with the Scriptures and the Confessions has led to disingenuous polity in the form of G-6.0106b: we state one thing, but actually mean something else. No wonder that ordaining and/or installing bodies are caught up in the semantics of exactly what words mean and how to apply them, such as 'chastity,' 'repentance,' and 'self-acknowledge.' Unclear wording and meaning leads to complaints, which, in turn, tie up the ecclesiastical court system for years.

The 2006 General Assembly received the long-awaited 2005 Peace, Unity, and Purity (PUP) Report by the Theological Task Force (TTF), which was appointed by the 2001 General Assembly. The Task Force did not recommend that G-6.0106b be deleted and/or amended, in fact, their report was based on the premise that it would be retained. Recommendation 5 of the Report asked the 2006 General Assembly to issue a new Authoritative Interpretation on G-6.0108 (PC(USA) Minutes 2006:514). The General Assembly approved it, with an addition in Subpart d (underlined) (PC(USA) Minutes 2006:28-29):

a. 'The Book of Confessions' and the Form of Government of the 'Book of Order' set forth the scriptural and constitutional standards for ordination and installation.

$b$. These standards are determined by the whole church, after the careful study of Scripture and theology, solely by the constitutional process of approval by the General Assembly with the approval of the presbyteries. These standards may be interpreted by the General Assembly and its Permanent Judicial Commission.

c. Ordaining and installing bodies, acting as corporate expressions of the church, have the responsibility to determine their membership by applying these standards to those elected to office. These determinations include:

(1) Whether a candidate being examined for ordination and/ or installation as elder, deacon, or minister of Word and Sacrament has departed from scriptural and constitutional standards for fitness for office,

(2) Whether any departure constitutes a failure to adhere to the essentials of Reformed faith and polity under G-6.0108 of the 'Book of Order', thus barring the candidate from ordination and/or installation.

d. Whether the examination and ordination and installation decision comply with the Constitution of the PC(USA), and whether the ordaining/installing body has conducted its examination reasonably, responsibly, prayerfully, and deliberately in deciding to ordain a candidate for church office is subject to review by higher governing bodies.

e. All parties should endeavor to outdo one another in honoring one another's decisions, according the presumption of wisdom to ordaining/installing bodies in examining candidates and to the General Assembly, with presbyteries' approval, in setting standards.

(PC(USA) Minutes 2006:515)

Paragraph G-6.0108 was added in 1983 and required candidates for office to adhere to the essentials of Reformed faith and polity. It also ensured freedom of conscience in the interpretation of Scripture within certain bounds. Thus, G-6.0108 made a serious distinction between standards and essentials. Departures from standards not deemed essential were permitted, but a governing body must discern what the essentials were (PC(USA)
Minutes 2006:515). However, the reality was that ordaining and installing bodies had either dispensed with standards, or put higher standards in place. The new Authoritative Interpretation would not introduce anything new, but affirm the power of the whole church to set standards, and not allow local options. The Authoritative Interpretation reaffirmed two principles from 1729: the elected officers must conform to the essentials of faith and polity and have the right of freedom of conscience with certain bounds; and governing bodies must apply standards and discern which were essential for ordained service (PC(USA) Minutes 2006:516).

The stated clerk of the General Assembly, Rev Dr C. Kirkpatrick, clearly stated that G-6.0106b was not a mandatory provision, but a ordination standard which could be scrupled (PC(USA) Office of the General Assembly 2007, PC(USA) Constitutional Services 2006:3). Specifically, subscription and prescriptive answers, which existed from 1910-1927 through the 'five fundamentals,' were forbidden when the Report of the Special Commission of 1925 was approved by the 1927 General Assembly (cf. PCUSA Minutes 1927) and this principle was reaffirmed by the 1981 GAPJC ruling in Rankin, et al. v. National Capital Union Presbytery (PC(USA) Constitutional Services 2006:1-3, cf. UPCUSA Minutes 1981:113-117, Vermaak 2010).

The result of the new 2006 Authoritative Interpretation on G-6.0108 was that some presbyteries adopted their own set of essential tenets, which was binding on all minister members. This led to several ecclesiastical trials - namely the Davis, Bush, Buescher, and Washington, 1793 rulings. Appeals and trials also followed when Ms L. Larges, Mr S. Anderson and Dr P. Capetz utilised the 2006 Authoritative Interpretation and declared scruples regarding G-6.0106b.

The 2006 GAPJC ruling, in Session of Colonial Presbyterian Church in Kansas City, MO v. Session of Grace Covenant Presbyterian Church in Overland Park, KS, was in regard to the irregularity and a delinquency in the examination, ordination and installation of one of the elders-elect of Session of Grace Covenant Presbyterian Church in Overland Park, Kansas (Grace) (PC(USA) Minutes 2008:298). However, the GAPJC did not follow its own guidance set in the 2002 Wier II, 2003 McKittrick or 2003 San Joaquin rulings. Not once did the GAPJC mention that no evidence of self-acknowledgement by the elder existed, or that Colonial had provided clear and palpable evidence to prove the elder was a self-acknowledged lesbian (PC(USA) Minutes 2008:299).

Colonial's arguments and evidence were simply unconvincing, yet the GAPJC reversed both the PJC of the Presbytery of the Heartland (PPJC) and the PJC of the Synod of Mid-America (SPJC) decisions on the narrow question of whether Grace had conducted a sufficient examination of the elders-elect (PC(USA) Minutes 2008:300). It also instructed the presbytery to appoint a special administrative review to determine if the examination of the elder-elect was not sufficient (PC(USA) Minutes 2008:299). During the trial, it was not established that any elder had selfacknowledged any sexual practice, nor was there any clear and palpable evidence, which the Wier II ruling required. The PPJC found that Grace had not violated the Constitution and the case was closed (McKell 2008).

The 2007 GAPJC, in Stewart v. Mission Presbytery, ruled that the case was moot since the candidate had asked to be removed and had been removed from the roll of candidates of Mission Presbytery (PC(USA) Minutes 2008:306). However, the GAPJC noted with concern that both Mission Presbytery and the PJC of the Synod of the Sun (SPJC) appeared to have relied on the Book of Order: Annotated Edition entry for the 2000 GAPJC ruling in the Sheldon case, rather than on the language of the case itself. The Book of Order: Annotated Edition, under G-14.0305d, provided an erroneous explanation of the Sheldon ruling, in stating that ' $[\mathrm{a}] \mathrm{n}$ inquirer may be received as a candidate even if not currently eligible for ordination because of G-6.0106b, 
but could not be ordained if found at the time for certification of readiness for ordination not to be in compliance' (PC(USA) Minutes 2008:307).

The GAPJC pointed out that this entry was a misstatement of the case. The Sheldon case pertained to a celibate gay man who was eligible to become a candidate since he had not violated the standard of G-6.0106b. The GAPJC ruling in Sheldon concluded:

However, if the [Presbytery] should determine the Candidate to be ineligible for candidacy at some point in the future, the [Presbytery] should remove the Candidate's name from the roll of candidates, as provided by G-14.0312

(PC(USA) Minutes 2008:307)

The provision was built into the Sheldon ruling that if a candidate became ineligible - not remain celibate - the candidate could no longer be a candidate since it would violate G-6.0106b. Thus, the GAPJC extended the ordination standards required of ministers also to inquirers who advance to candidates for ministry (Silverstein 2007:1), not just candidates and candidates ready to receive a call. Thus, self-acknowledged gays and lesbians were not eligible to advance from inquirer to candidate, unless they became celibate.

The 2007 PJC of the Synod of the Pacific (SPIC), in Session of Davis Community Church, et al. v. Sacramento Presbytery, ruled that the four resolutions by the presbytery were unconstitutional (PJC of the Synod of the Pacific 2007:4, 6). Resolution 1 stated that:

... Sacramento Presbytery holds that all candidates for ordination, installation, and/or membership in the Presbytery shall comply with all standards for ordination set forth in the Constitution ... or shall be ineligible for ordination, installation and/or membership.

Resolution 2 stated that:

... Sacramento Presbytery shall not receive into membership, nor recognize as a member anyone who has been ordained or installed under a scruple that is taking exception to any ordination standards as set forth in the Constitution...

(PJC of the Synod of the Pacific 2007:2)

This meant no scruples would be allowed by the presbytery. The SPJC concluded that a presbytery may not $a$ priori exclude persons who declared a scruple within the acceptable standards, but must decide if a particular scruple disqualified someone from ordained office. Also, a presbytery is not entitled to set new standards which impose greater limitations on ordination or conversely remove the stated impediments to ordination (PJC of the Synod of the Pacific 2007:10).

The 2008 GAPJC, in Bush, et al. v. Presbytery of Pittsburgh, ruled that departures from the church's standards of belief were allowed, but not departures from behaviour:

... [t]he specific 'fidelity and chastity' standard in G-6.0106b stands in contrast to the provisions of G-6.0106a ... The candidate and examining body must follow G-6.0108 in reaching a determination as to whether the candidate for office has departed from essentials of Reformed faith and polity, but that determination does not rest on distinguishing 'belief' and 'behavior,' and does not permit departure from the 'fidelity and chastity' requirement found in G-6.0106b.

The freedom of conscience granted in G-6.0108 allows candidates to express disagreement with the wording or meaning of provisions of the constitution [sic - capitalised], but does not permit disobedience to those behavioral standards.

(PC(USA) Minutes 2008:322)

The GAPJC also found that G-6.0106b was an essential standard and no departure or scruple would be allowed. The GAPJC, in this decision, made one part of the Book of Order an essential standard, and elevated sexual standards above all other required standards to hold office. It also issued a new Authoritative Interpretation, thus setting aside the 2006
Authoritative Interpretation of the 2006 General Assembly based on the 2005 PUP Report, which did not equate polity with behaviour. In essence, the GAPJC moved the denomination dangerously close to subscription, which Presbyterians have rejected since 1927 with the Report of the Special Commission of 1925 (PCUSA Minutes 1927) and the 1981 Rankin ruling (UPCUSA Minutes 1981:113-117, see Vermaak 2010).

The 2008 GAPJC, in Buescher, et al. v. Presbytery of Olympia, relying heavily on the 2008 Bush ruling, declared a resolution by the presbytery to be unconstitutional. The GAPJC reaffirmed that the 2006 Authoritative Interpretation did not and could not change ordination standards, including the requirements of G-6.0106b. Attempts by governing bodies to restate provisions of the Book of Order and/or declaring them as essentials of Reformed faith and polity were confusing and unnecessary (PC(USA) Minutes 2008:318). Also, by declaring, in advance, the mandates to be 'essentials', and by establishing, in advance, the mandates to be an absolute bar to ordination and installation, the presbytery violated G-6.0108 and the (2006) Authoritative Interpretation (PC(USA) Minutes 2008:319).

The 2008 GAPJC, in Session of First Presbyterian Church of Washington, 1793, et al. v. Presbytery of Washington, affirmed that presbyteries should not create their own essential articles which candidates had to abide by. The GAPJC noted:

Contrary to the Presbytery's assertions, the Adopting Act of the nineteenth of September, 1729 (Adopting Act), incorporates the term 'necessary and essential' four times. Moreover, it provides instructive historical guidance for the application and interpretation of G-6.0108a and $b$ (as to essentials). This Commission does note that later re-affirmations of the Adopting Act do not include the term 'necessary and essential.' The Church is therefore urged to use original sources of this and other historic documents and not to rely upon re-statements or paraphrases.

(PC(USA) Minutes 2008:327)

The GAPJC was correct that 'essential' was mentioned in the Adopting Act of 1729 , but exactly what the essentials were was not specified, nor have they ever been specified in the entire history of the Presbyterian Church since 1729. The GAPJC, however, in the Bush ruling, which was issued on that same day, specified that G-6.0106b was an essential.

The 2008 General Assembly, in turn, approved an overture and voted to replace the 2008 GAPJC ruling, in Bush, et al. $v$. Presbytery of Pittsburgh, which overruled the 2006 Authoritative Interpretation of G-6.0108 to allow scruples, with a new Authoritative Interpretation, which allowed scruples, including of G-6.0106b:

The 218th General Assembly (2008) affirms the authoritative interpretation of G-6.0108 approved by the 217th General Assembly (2006). Further, the 218th General Assembly (2008), pursuant to G-13.0112, interprets the requirements of G-6.0108 to apply equally to all ordination standards of the Presbyterian Church (U.S.A.). Section G-6.0108 requires examining bodies to give prayerful and careful consideration, on an individual, caseby-case basis, to any departure from an ordination standard in matters of belief or practice that a candidate may declare during examination. However, the examining body is not required to accept a departure from standards, and cannot excuse a candidate's inability to perform the constitutional functions unique to his or her office (such as administration of the sacraments).

(PC(USA) Minutes 2008:380)

The 2008 General Assembly sent an amendment to delete and amend G-6.0106b to the presbyteries for their vote, but it was defeated by a 95-78 vote (The Layman 2009:1). Additionally, the General Assembly issued an Authoritative Interpretation, which was not dependent upon the outcome of the vote on the amendment of G-6.0106b: 
Interpretive statements concerning ordained service of homosexual church members by the 190th General Assembly (1978) of the United Presbyterian Church in the United States of America, and the 119th General Assembly (1979) of the Presbyterian Church in the United States and all subsequent affirmations thereof, have no further force or effect.

(PC(USA) Minutes 2008:373)

Thus, the 1978 and 1979 'definitive guidance' statements, reaffirmations thereof, and four GAPJC rulings up to 1997, predicated upon the 'definitive guidance,' no longer had any effect - namely, Blasdell in 1985, LeTourneau in 1992, Sallade in 1992, and Hope in 1993 (PC(USA) Constitutional Services 2008b:1-2). Thus, only GAPJC rulings and Authoritative Interpretations issued by General Assemblies from 1997, predicated upon G-6.0106b, are in effect, namely Wier I in 1998, Sheldon in 2000, Benton in 2000, Londonderry in 2000, Wier II in 2002, San Joaquin in 2002, McKittrick in 2003, and Stewart in 2007 (PC(USA) Constitutional Services 2008a:2).

One should note that the General Assembly and the GAPJC have repeatedly defined 'self-acknowledgement' of sin as the key to applying G-6.0106b. The 2009 GAPJC, in Bierschwale, et al. v. Presbytery of Twin Cities Area (Bierschwale I) ruled that the restoration of a celibate gay, Dr P. Capetz, to the ministry of the Word and Sacrament in January 2008 by the Presbytery of Twin Cities Area (Presbytery) was in order. Capetz utilised the 2006 Authoritative Interpretation and declared a scruple over G-6.0106b, despite being a celibate gay (PC(USA) GAPJC 2009a:5). The GAPJC, however, reiterated that Capetz had to abide by G-6.0106b, despite declaring a scruple over it. The GAPJC also issued a shocking statement: 'This Commission cannot reach the questions raised by the parties in this appeal as to the validity and effect of the 2008 Authoritative Interpretation (AI) on G-6.0108b or whether Bush has effectively been overruled by the 2008 Authoritative Interpretation' (PC(USA) GAPJC 2009a:6).

This statement must be seen in light of the 2008 General Assembly, which clearly stated that the 2008 GAPJC ruling in the Bush decision had been revoked (PC(USA) Minutes 2008:380). The above statement shows the growing concern regarding the Authoritative Interpretations issued by the GAPJC, which become the polity of the PC(USA). The GAPJC found that the PJC of the Synod of Lakes and Prairies (SPJC) erred in not holding a trial to determine whether Capetz stated a departure from G-6.0106b and, if so, whether that departure was a failure to adhere to G-6.0108 and whether the presbytery's action was irregular. The SPJC also failed to determine whether the presbytery waived the 'fidelity and chastity' requirement of G-6.0106b (PC(USA) GAPJC 2009a:3-4). The GAPJC instructed the SPJC to hold a trial (PC(USA) GAPJC 2009a:7).

The SPJC held a trial and found that Capetz had declared a departure from G-6.0106b, which did not infringe on the rights and views of others. Bierschwale, et al. again filed a complaint with the GAPJC specifying eight errors by the SPJC. The GAPJC, in Bierschwale, et al. v. Presbytery of Twin Cities Area (Bierschwale II) did not sustain any of the specifications of error and reaffirmed the SPJC ruling (PC(USA) GAPJC 2009b:2-6). Interestingly, the GAPJC commented on Capetz' scruple to refuse to take a vow of celibacy. It concluded that 'G-6.0106b requires "fidelity in marriage between a man and a woman ... or chastity in singleness," not celibacy. The Presbytery concluded that Capetz did not fail to "adhere to the essentials of Reformed faith and polity" by refusing to take a vow of celibacy. This Commission concurs' (GAPJC PC(USA) 2009b:4). Regarding future conduct, the GAPJC stated that 'Capetz' statements about his possible future conduct do not provide a foundation for finding a present violation of G-6.0106b' (GAPJC PC(USA) 2009b:5).

The 2009 PJC of the Synod of the Pacific (SPJC), in Naegeli, et al. $v$. Presbytery of San Francisco, nullified and declared without force or effect the vote of the Presbytery of San Francisco (Presbytery) to certify a candidate (for ministry), Ms L. Larges, 'is ready for examination, effective January 15, 2008, with a departure' (PJC of the Synod of the Pacific 2009:5). Larges, a lesbian candidate since 1986, utilised the 2006 Authoritative Interpretation and declared a scruple regarding G-6.0106b with the CPM, but was not examined by the presbytery. The SPJC ruled that the presbytery could not consider Larges' objection:

... [b]ecause the examination for ordination is the proper time for Presbytery to determine whether or not a candidate's departure constitutes a failure to adhere to the essentials of Reformed faith and polity ('Theological Task Force on Peace, Unity and Purity of the Church', Recommendation 5, c. 1-2, ('Minutes' 2006, p. 514) The debate and vote on January 15, 2008 was not an examination for ordination. The language of the motion on the floor was to certify the candidate as 'ready for examination ... with departure', thus an examination could not yet properly take place in advance of such certification.

(PJC of the Synod of the Pacific 2009:5)

Thus, the SPJC found that the presbytery's debate and vote did not constitute an examination of Larges; it violated the requirement that those being examined appear personally before the presbytery and make a brief statement of personal faith (G-14.0482 Book of Order) (PJC of the Synod of the Pacific 2009:5). However, the complainants were still dissatisfied with the ruling and filed an appeal with the GAPJC with eight specifications of error. Notably they argued that the SPJC failed to rule that G-6.0106b was a church-wide mandatory ordination standard that cannot be waived, thus an essential in their view and that the SPJC should have instructed the presbytery to remove the candidate from the roll of candidates. The GAPJC upheld the SPJC's decisions that Larges had not been examined and, therefore, the Presbytery had not considered whether Larges had departed from essentials of Reformed faith and polity set forth in G-6.0108b (PC(USA) GAPJC 2009c:4-9). Larges later declared a scruple on G-6.0106b during her examination by the presbytery and was approved by a 156-138 vote for ordination in a validated ministry with That All May Freely Serve. Naegeli, et al. filed a stay of enforcement with the PJC of the Synod of the Pacific right after the meeting (Scanlon 2009:1), and two presbyteries and a session also joined the complaint (Terry 2010a:1).

One needs to note that the 2009 GAPJC in the Naegeli ruling indirectly changed its 2007 Stewart ruling in affirming the SPJC ruling that the proper time for a presbytery to consider a scruple, and whether it disqualifies the candidate, is during the examination for ordination, not during the CPM's certification for readiness stage (Scanlon 2009:2). Thus, it would seem that persons advancing to the inquirer and candidate stages can no longer be asked about their sexual practice, since they are unable to declare a scruple at that point. They can only declare a scruple once they are candidates ready to be ordained. The Stated Clerk of the General Assembly confirmed this to the Presbytery of the Pacific, where I am a member, in preparation for its vote to advance a partnered gay inquirer to candidate in January 2010.

In February 2010 the John Knox Presbytery voted 81-25 to ordain Mr S. Anderson - a gay man who had given up his ordination as a minister of the Word and Sacrament in 1990 after he declared a scruple on G-6.0106b (Scanlon 2010:1). The Session of Caledonia Presbyterian Church, four ministers and an elder filed a remedial complaint with the PJC of the Synod of Lakes and Prairies and it granted a stay of enforcement on Anderson's ordination (PJC of the Synod of Lakes and Prairies 2010:1-4). The Central Florida and Stockton Presbyteries also joined the complaint (Terry 2010b, c).

\section{THE CURRENT POLITY}

Can a gay or lesbian person become an officer in the PC(USA)? Presbyterians will disagree on the answer; it depends upon many factors. The current PC(USA) polity is that a gay or lesbian 
sexual orientation is not a bar to ordination and/or installation, but same-gender sexual practice could be. Celibate gay and lesbian candidates can be ordained and/or installed as officers. If they no longer remain celibate and when clear, palpable evidence or even hearsay of a same-gender relationship is presented, a disciplinary complaint could be filed against them. The 2006 and 2008 General Assemblies issued Authoritative Interpretations which permit scrupling of G-6.0106b. A partnered gay or lesbian person, who becomes an inquirer or candidate for the ministry of the Word and Sacrament, whether or not their relationship is common knowledge to their CPM, is exempt from questions regarding their sexual activity; they do not have to declare a scruple. When a partnered gay or lesbian candidate or minister receives a call, or a minister applies for minister-at-large or validated ministry status within a presbytery, or a person is elected to be a deacon or an elder, and the CPM or COM or session respectively has plain, palpable, and obvious evidence of a person's relationship status, according to the Wier II standard, it has the positive obligation to make further inquiry of a candidate. When questioned about their sexual activity or relationship, an officer-elect has the following options (1) decline to answer the question, (2) decline to answer the question and declare that they have no self-acknowledged sin to confess, since they believe their committed same-gender relationship is not sinful, (3) answer the question and declare that they have no self-acknowledged sin to confess and (4) answer the question and declare a scruple regarding G-6.0106b.

If the candidate, minister, deacon or elected or elder declares a scruple, the presbytery or session - which cannot waive the constitutional requirements for ordination and/or installation - votes whether the candidate's scruple is permissible under the 2006 and 2008 Authoritative Interpretations and does not violate an essential of the Reformed faith and polity. Thus, sessions and presbyteries have to determine whether the officer-elect's scruple is a non-essential article. This has been, and always will be, a subjective judgment in the absence of defined essentials and necessary articles of the Reformed faith and polity.

If the ordaining body votes 'yes,' the candidate advances, the minister is enrolled, and the deacon elected or elder is ordained and/or installed. However, complaints could still be filed with the PJC of the local presbytery or synod. The 2009 GAPJC, in Bierschwale I, re-affirmed the restoration of Capetz under a scruple, but ' ... Capetz is fully accountable under all standards and requirements for Ministers of [sic - the] Word and Sacrament to abide by the Constitution of the PC(USA), including G-6.0106b' (PC(USA) GAPJC 2009a:6) and in Bierschwale I and II that '... Capetz still may be subject to disciplinary action based on his conduct' (PC(USA) GAPJC 2009a:6, 2009b:5).

Finally, the polity battle over partnered gay and lesbian ordination and/or installation standards, in the absence of theological discussion, will continue at both the General Assembly and presbytery level. Since the 1978 and 1979 'definitive guidance' statements and affirmations thereof in the form of Authoritative Interpretations have all been deleted, the PC(USA) is left with the intent of G-6.0106b self-acknowledgement of sin - and the practice of declaring scruples, including G- 6.0106b. However, as the 2009 Bierschwale I and II and Naegeli rulings have shown, it is not clear cut that one can merely declare a scruple and be approved through majority vote. The 2006 and 2008 General Assemblies simply did not specify the details or procedures of scrupling, thus the Bierschwale I and II and Naegeli complaints merely pertained to procedural errors.

\section{CONCLUSION}

In 1927, when the General Assembly of the PCUSA adopted the Report of the Special Commission of 1925, it gave precedence to polity over theology (Vermaak 2010, cf. Journal of Presbyterian History 2001). The predecessor churches of the PC(USA) - the
UPCUSA and PCUS - both put policy statements in place, i.e. the 1978 and 1979 'definitive guidance' statements, rather than deal with the biblical and theological discussion of gay and lesbian ordination. The absence of theological discussion and the preponderance of issues solved through polity are evident at both the presbytery and General Assembly levels. Commissioners discuss overtures and amendments on polity, but do not engage in theological discussion or biblical exegesis of the texts regarding same-gender relationships.

Thus, Presbyterians' view of ordination has become stagnant and polity-driven, without fresh theological input as to whether God could and does call partnered and monogamous gay and lesbian Christians to ordained service through the voice of a nominating committee, the congregation, and the presbytery. The church needs to re-examine its teachings about both the vocation of gay and lesbian Christians as ministers, and same-gender relationships, in light of biblical, theological, and confessional standards. In fact, the meaning of ordination needs to be re-examined.

In the absence of theological discussion, polity has become the means to solve the more than 40-year-long ordination and/or installation debate. Additionally, the focus has been solely on same-gender relationships. The sexual dimension of Christian life has been elevated over other aspects that receive equal or greater emphasis in Scripture and the Confessions: the high divorce rate, social injustice, the church's role in society, the church's mission, capitalism, consumerism, individualism, environmentalism, racism, etc. The PC(USA) has not developed a theology of sexuality, sexual expression, and relationships of all people. Rogers (1995:134-135) affirms this:

Only after dealing with the moral question of appropriate sexual relationships can we deal with the issue of ordination of homosexuals. Then we would have to deal with gay and lesbian persons not as a class of people but individually according to the same standards of knowledge, competence, and personal morality by which we judge other candidates for ordination.

In 1983, the UPCUSA, and a few days later the re-uniting PC(USA), both adopted the Report of the Special Committee on Historic Principles, Conscience, and Church Governance. Regarding the relationship between polity and theology, it stated:

The basis of Presbyterian polity is theological. Our polity is not just a convenient way of getting things done; it is rather the ordering of our corporate life which expresses what we believe. The connection between faith and order is inseparable. At its heart, the polity of the church expresses our Reformed theology. What we do and the way we do it is an expression of how we understand our faith.

(PC(USA) Minutes 1983:145)

However, polity without a theological component has increasingly become the way through which Presbyterians adjudicate their theological differences. Polity has become more important than theology in the light of religious pluralism (McCarthy 1992:302-303). The danger is that polity has replaced theology in the Presbyterian decision-making process regarding our gay brothers and lesbian sisters. Thus, even when G-6.0106b is finally deleted from and/or amended in the Book of Order, the polity battle over same-gender relationships will continue.

\section{REFERENCES}

Adams, J.H., 2002, 'Vermont session again spurns order by highest PCUSA [sic - PC(USA)] court', The Layman Online 10 December, viewed on 29 March 2009, from http://www.layman.org/layman/news/news-frompcusa/vermont-session-again.htm

Anderson, J.D., 1993, More Light Update April, viewed on 28 March 2009, from http://www.qrd.org/qrd/orgs/PLGC/ newsletters/1993/04.93 
Anderson, J.D., 1994, The Lesbian and Gay Liberation Movement in the Churches of the United States, 1969-1993. With Special Reference to Presbyterians for Lesbian $\mathcal{E}$ Gay Concerns, 19741993, viewed on 28 March 2009, from http://www.mlp.org/ resources/history.html

McCarthy, D.B., 1992, The Emerging Importance of Presbyterian Polity, in M.J. Coalter, J.M. Mulder, \& L.B. Weeks (eds.), The Organizational Revolution: Presbyterians and American Denominationalism, Westminster John Knox Press, Louisville, 279-306.

North Como Presbyterian Church, 2005, Ordination Standards: Biblical, Theological, and Scientific Perspectives, iUniverse, Lincoln.

PCUS, 1977, The Church and Homosexuality: A Preliminary Study, 1977, Office of the General Assembly, Louisville, reprinted in Definitive Guidance: The Church's Statements on Homosexuality, PC(USA) 2004a:1-40.

PCUS, 1979a, PCUS, Homosexuality and the Church.

PCUS, 1979b, Homosexuality and the Church: A Position Paper, 1979.

PCUS Minutes, Minutes of the General Assembly, Part I: Journal, Office of the General Assembly, Louisville.

PCUSA Minutes, 1927, Minutes of the General Assembly: Report of the Special Commission of 1925, [s 1], 58-86.

PCUSA, 2001, 'Report of the Special Commission of 1925 (Excerpt)', Journal of Presbyterian History 79(1), 46-52, reprint of PCUSA Minutes 1927:77-86, viewed 28 March 2009, from http://www.history.pcusa.org/pubs/journal/2001/2001_ spring/046-052.pdf

PC(USA), 2004a, Definitive Guidance: The Church's Statements on Homosexuality, Westminster John Knox Press, Louisville.

PC(USA), 2004b, The Book of Confessions. The Constitution of the Presbyterian Church (U.S.A.), Part I, Office of the General Assembly, Louisville.

PC(USA), 2005, A Season of Discernment: The Final Report of the Theological Task Force on the Peace, Unity, and Purity of the Church to the 217th General Assembly (2006) with Study Guide, viewed on 28 March 2009, from http://www.pcusa.org/ peaceunitypurity/finalreport/final-report-revised-english. pdf

PC(USA), 2009-2011, Book of Order. The Constitution of the Presbyterian Church (U.S.A.), Part II, Office of the General Assembly, Louisville.

PC(USA) Constitutional Services, 2006, Constitutional Musing Note 11 Examining Officers, viewed on 28 March 2009, from http://www.pcusa.org/constitutionalservices/musings/ note11.pdf

PC(USA), Constitutional Services 2008a, Advisory Opinions: Note 21 Ordination Standards and Examinations Essentials, Reformed Faith and Polity, viewed on 28 March 2009, from http:// www.pcusa.org/constitutionalservices/ad-op/note21.htm

PC(USA) Constitutional Services, 2008b, Advisory Opinions: Note 22 Actions of the 218th General Assembly related to G-6.0106b and G-6.0108, July, viewed on 29 March 2009, http:// www.pcusa.org/constitutionalservices/ad-op/advisoryopinion22.pdf

PC(USA) GAPJC, 2009a, Bierschwale, et al. v. Presbytery of the Twin Cities Area. Decision and Order in Remedial Case 219-0, 2 March, viewed on 13 March 2009, from http://www.pcusa. org/gapjc/decisions/pjc21908.pdf

PC(USA) GAPJC, 2009b, Bierschwale, et al. v. Presbytery of the Twin Cities Area. Decision and Order in Remedial Case 219-08, 2 November, viewed 4 November 2009, from http://www. pcusa.org/gapjc/decisions/pjc21908b.pdf

PC(USA) GAPJC, 2009c, Naegeli, et al. v. Presbytery of San Francisco. Decision and Order in Remedial Case 219-11, 2 November, viewed 4 November 2009, from http://www.pcusa.org/gapjc/ decisions/pjc21911.pdf

PC(USA) Minutes, Minutes of the General Assembly, Part I: Journal, Office of the General Assembly, Louisville.
PC(USA) Office of the General Assembly, 2007, 'Response from the Office of the General Assembly: Proposed Understanding - Mandatory Standards and G-6.0106b', Presbyterian Outlook, 12 February.

PJC of the Synod of Lakes and Prairies, 2010, The Session of Caledonia Presbyterian Church, et al. v. John Knox Presbytery. Complaint, 2 March.

PJC of the Synod of the Pacific, 2007, Session of Davis Community Church, et al. v. Sacramento Presbytery. Decision in Remedial Case 06-03, 16 June, viewed on 28 March 2009, from http:// synodpacific.org/documents/DavisvsSacramento.pdf

PJC of the Synod of the Pacific, 2009, Naegeli, et al. $v$. Presbytery of San Francisco. Final Decision and Order in Remedial Case 08-01, 20 March, viewed 10 February 2010, http://www.pcusastandards.org/images/Naegeli\%20v.\%20 SFP\%20decision.pdf

Rogers, J.B., 1995, Claiming the Center: Churches and Conflicting Worldviews, Westminster John Knox Press, Louisville.

Scanlon, L., 2009, 'Presbytery votes to permit Larges ordination; stay of enforcement sought', Presbyterian Outlook, 11 November.

Scanlon, L., 2010, 'Scott Anderson approved for ordination', The Presbyterian Outlook, 22 February, viewed on 25 February, from http://pres-outlook.net/component/content/ article/44-breaking-news/9703-scott-anderson-approvedfor-ordination.html

Shafer, B.E., 1978, 'The Church and Homosexuality', in The Church and Homosexuality, The United Presbyterian Church in the United States of America, 9-56, viewed on 27 March 2009, from http://www.pcusa.org/oga/publications/church-andhomosexuality.pdf

Silverstein, E., 2007, 'PJC says ordination standards include ministerial candidates', Presbyterian News Service, 14 May, viewed on 28 March 2009, from http://www.pcusa.org/ pcnews/2007/07280.htm

Terry, E., 2010a, 'More could join San Francisco complaint', The Layman Online, 23 February, viewed 5 March 2010, from http:// layman.org $/$ News.aspx?article $=26766$

Terry, E., 2010b, 'Central Florida joins complaint against John Knox Presbytery', The LaymanOnline, 30 April, viewed on 5 May, from http://www.layman.org/news. aspx?article $=26971$

Terry, E., 2010c, 'Stockton Presbytery joins John Knox complaint', The Layman Online, 6 May, viewed on 11 May, from http:// www.layman.org/News.aspx?article $=26987$

The Adopting Act of 1729, viewed on 27 March 2009, from http://www.pcahistory.org/documents/subscription/ adoptingact.html

The Layman, 2009, 'Presbyteries vote for the 5th time on sex issues', The Layman Online, viewed on 4 June 2009, from http://layman.org/Home/Special_Reports/Vote_Chart.aspx

UPCUSA, 1970, Sexuality and the Human Community, Distribution Management Services, Louisville, viewed on 28 March 2009 from http://www.pcusa.org/oga/publications/sexualityand-human-community.pdf

UPCUSA, 1978a, The Church and Homosexuality: Policy Statement on Homosexuality, Office of the General Assembly, Louisville.

UPCUSA, 1978b, The Church and Homosexuality:Preface, Office of the General Assembly, Louisville.

UPCUSA Minutes, Minutes of the General Assembly, Part I: Journal, New York.

Vermaak, R.F., 2009, 'A historical study of the polity of the gay and lesbian ordination and/or installation, and samegender marriage debates in the Presbyterian Church (U.S.A.) and its predecessor churches', PhD thesis, Faculty of Theology, University of Pretoria, Pretoria, viewed on 10 October 2009, from http://upetd.up.ac.za/thesis/available/ etd-07042009-213526

Vermaak, R.F., 2010 [in press], 'The historical development of Presbyterian ordination polity as background to the gay and lesbian ordination debate in the Presbyterian Church (U.S.A.)', Verbum et Ecclesia 31(1). 